\title{
HYPERTHERMIA INDUCED BY THYROTROPIN-RELEASING HORMONE (TRH, PROTIRELIN) IN THE RAT
}

\author{
YASUTAKA NODA ${ }^{1)}$, MASATOSHI TANAKA ${ }^{2)}$, HIDEKI KOJIMA ${ }^{3)}$ \\ AND KAZUTOYO INANAGA ${ }^{4}$ )
}

\begin{abstract}
Institute of Animal Experiment ${ }^{1)}$, Department of Pharmacology ${ }^{2)}$, Institute of Brain Diseases ${ }^{3)}$ and Department of Neuropsychiatry ${ }^{4}$, Kurume University School of Medicine, Kurume, 830, Japan
\end{abstract}

Received for publication June 5, 1979

\begin{abstract}
The effect of the thyrotropin-releasing hormone (TRH, protirelin), one of the hypothalamic releasing hormones, on body temperature was investigated in the rat. TRH tartrate dissolved in saline, in doses of 1, 5, 10 and $20 \mathrm{mg} / \mathrm{kg}$, was injected intraperitoneally to male Wistar rats weighing 200-250 g. The rectal temperature was measured with the electronic thermister inserted into $5 \mathrm{~cm}$ inner from the anus. TRH tartrate caused a temporary rise in body temperature dose-dependently. The degree of the rise in body temperature ranged from $0.5^{\circ} \mathrm{C}$ to $1.5^{\circ} \mathrm{C}$ as a mean and the hyperthermia appeared early and lasted for $80 \mathrm{~min}$ after the peptide administration. The thyroidectomized rats injected $20 \mathrm{mg} / \mathrm{kg}$ of TRH which induced a significant hyperthermia in the sham-operated animals, failed to show a rise in body temperature. The present results suggest that a release of thyroid hormone might participate in the hyperthermic action of TRH.
\end{abstract}

\section{INTRODUCTION}

Recently, many literatures on neurohormones have been published. Among the peptides in the brain, thyrotropinreleasing hormone ( $\mathrm{TRH}$, protirelin) has been studied not only because of its usefulness for diagnostic and/or therapeutic aspects of neuroendocrinological disorders but also because of its efficacies on some psychiatric disorders.

Prange and Wilson (1972a) and Prange et al. (1972b) reported TRH was effective in depressed patients and the results were supported by other authors. However, Takahashi et al. (1973) described this peptide was not useful for the treatment of these patients. Inanaga et al. (1975 a, 1975b) reported TRH given with a combination of neurolep- tics improved symptoms in some type of schizophrenics and these results have been confirmed by the double-blined controlled study of TRH in schizophrenic patients (Inanaga et al. 1978).

In addition to these clinical values of $\mathrm{TRH}$, it has also been reported that TRH not only antagonized the hypothermia induced by chlorpromazine in mice, rats and rabbits (Kruse 1975) and by pentobarbital in rodents (Prange et al. 1974) and ethanol narcosis in mice (Breese et al. 1974) but also potentiated the action of L-DOPA (Plotnikoff et al. $1974 \mathrm{a}, 1974 \mathrm{~b}$ ). According to their reports, the action of TRH on body temperature has been considered to be independent of thyroid hormone releasing action. In the present study, the authors, however, describe the possibility 
that a release of thyroid hormone might have a close relation to the hyperthermia induced by TRH in the rat.

\section{METHODS}

Ninety male Wistar rats weighing $200-250 \mathrm{~g}$ were subjected to the study. In the first experiment, 50 rats were divided into five groups randomly. Four doses of TRH tartrate dissolved in physiological saline, i. e., $1 \mathrm{mg} / \mathrm{kg}, 5 \mathrm{mg} / \mathrm{kg}$, $10 \mathrm{mg} / \mathrm{kg}$ and $20 \mathrm{mg} / \mathrm{kg}$, were administered intraperitoneally to the four groups and saline to the remaining control group. Rectal temperature was measured at the place $5 \mathrm{~cm}$ inner from the anus with the electronic thermister (Nihon Kohden) before and after treatment with TRH or saline.

In the second experiment, 40 rats were thyroidectomized or sham-opera- ted under the anesthesia by thiopental sodium. Ten days after the operation, $20 \mathrm{mg} / \mathrm{kg}$ of TRH or saline was administered to the thyroidectomized and sham-operated animals by i. p. and rectal temperature was measured using the same method as used in the first experiment.

These two experiments were undertaken from $1 \mathrm{p}$. m. to $4 \mathrm{p}$. m. and the room temperature was kept at $24 \pm 1^{\circ} \mathrm{C}$ through the experiments including the breeding period.

For a statistical analysis, Student's t test (two-tailed) was adopted.

\section{RESULTS}

\section{The Effect of TRH on Rectal Temper-} ature in the Rat

The changes in the rectal temperature after treatmet with TRH and saline are shown in Table 1 . The rectal

TABLE 1

Effect of TRH on rectal temperature in the rat

\begin{tabular}{|c|c|c|c|c|c|c|c|c|c|}
\hline \multirow{2}{*}{$\begin{array}{l}\text { Treatment } \\
\text { (i.p.) }\end{array}$} & \multicolumn{9}{|c|}{ Rectal temperatures $\left({ }^{\circ} \mathrm{C}\right)$ at various time after TRH } \\
\hline & 0 & 20 & 40 & 60 & 80 & 100 & 120 & 180 & $\min$ \\
\hline Saline & $\begin{array}{c}37.9 \\
\pm \\
0.13\end{array}$ & $\begin{array}{c}38.4 \\
\pm \\
0.09\end{array}$ & $\begin{array}{c}38.3 \\
\pm \\
0.09\end{array}$ & $\begin{array}{c}38.2 \\
\pm \\
0.08\end{array}$ & $\begin{array}{c}38.1 \\
\pm \\
0.03\end{array}$ & $\begin{array}{c}38.1 \\
\pm \\
0.06\end{array}$ & $\begin{array}{c}37.9 \\
\pm \\
0.08\end{array}$ & $\begin{array}{c}38.0 \\
\pm \\
0.10\end{array}$ & \\
\hline $\mathrm{TRH} \quad 1 \mathrm{mg} / \mathrm{kg}$ & $\begin{array}{c}37.9 \\
\pm \\
0.04\end{array}$ & $\begin{array}{c}38.5 \\
\pm \\
0.08\end{array}$ & $\begin{array}{c}38.2 \\
\pm \\
0.10\end{array}$ & $\begin{array}{c}38.2 \\
\pm \\
0.04\end{array}$ & $\begin{array}{c}38.1 \\
\pm \\
0.08\end{array}$ & $\begin{array}{c}38.1 \\
\pm \\
0.06\end{array}$ & $\begin{array}{c}37.9 \\
\pm \\
0.08\end{array}$ & $\begin{array}{c}37.9 \\
\pm \\
0.07\end{array}$ & \\
\hline $\mathrm{TRH} \quad 5 \mathrm{mg} / \mathrm{kg}$ & $\begin{array}{c}37.9 \\
\pm \\
0.08\end{array}$ & $\begin{array}{c}38.6 \\
\pm \\
0.07\end{array}$ & $\begin{array}{c}38.3 \\
\pm \\
0.07\end{array}$ & $\begin{array}{c}38.4 \\
\pm \\
0.08\end{array}$ & $\begin{array}{c}38.2 \\
\pm \\
0.05\end{array}$ & $\begin{array}{c}38.1 \\
\pm \\
0.08\end{array}$ & $\begin{array}{c}38.1 \\
\pm \\
0.08\end{array}$ & $\begin{array}{c}38.0 \\
\pm \\
0.06\end{array}$ & \\
\hline $\mathrm{TRH} \quad 10 \mathrm{mg} / \mathrm{kg}$ & $\begin{array}{c}37.9 \\
\pm \\
0.05\end{array}$ & $\begin{array}{c}38.9 \\
\pm \\
0.11\end{array}$ & $\begin{array}{c}38^{* * *} \\
\pm \\
0.12\end{array}$ & $\begin{array}{c}38.5 \\
\pm \\
0.11\end{array}$ & $\begin{array}{c}38.3^{*} \\
\pm \pm \\
0.10\end{array}$ & $\begin{array}{c}38.4 \\
\pm \\
0.06\end{array}$ & $\begin{array}{c}38.3 \\
\pm \\
0.09\end{array}$ & $\begin{array}{c}38.0 \\
\pm \\
0.09\end{array}$ & \\
\hline $\mathrm{TRH} \quad 20 \mathrm{mg} / \mathrm{kg}$ & $\begin{array}{c}37.9 \\
\pm \\
0.05\end{array}$ & $\begin{array}{c}39.2 \\
\pm * \\
\pm .08\end{array}$ & $\begin{array}{c}39.3 \\
\pm * \\
\pm .07\end{array}$ & $\begin{array}{c}38.9 \\
\pm * \\
0.07\end{array}$ & $\begin{array}{c}38.5 \\
\pm * * \\
\pm .06\end{array}$ & $\begin{array}{c}38.3 \\
\pm \\
0.08\end{array}$ & $\begin{array}{c}38.2 \\
\pm \\
0.09\end{array}$ & $\begin{array}{c}38.0 \\
\pm \\
0.08\end{array}$ & \\
\hline
\end{tabular}

Each group consists of 10 rats. All groups treated with TRH were compared with the saline-treated group. Each value is shown as a mean \pm S. E.M.. Statistical significances are indicated as follows: ${ }^{*} \mathrm{P}<0.05,{ }^{* *} \mathrm{P}<0.01, * * * \mathrm{P}<0.001$ 
temperature of the rat injected $20 \mathrm{mg} /$ $\mathrm{kg}$ of TRH rose markedly 20 min after injection, reached to the peak at $40 \mathrm{~min}$, then gradually decreased and recovered to the range of saline injected rats approximately $100 \mathrm{~min}$ after. The increase in body temperature in the group treated with $20 \mathrm{mg} / \mathrm{kg}$ was statistically significant as compared with that in the saline group at 20,40,60 and 80 min after injection. Also, TRH $10 \mathrm{mg} /$ $\mathrm{kg}$ group showed a similar tendency; the rectal temperature increased significantly at 20,40 and $80 \mathrm{~min}$ and the maximum rise was obtained at $40 \mathrm{~min}$. In the rats injected 1 or $5 \mathrm{mg} / \mathrm{kg}$ of $\mathrm{TRH}$, no significant rise in rectal temperature was observed. This temporary hyperthermia induced by TRH occurred dose-dependently.

\section{The Effect of Thyroidectomy on Hyper- thermia induced by $T R H$}

As shown in Fig. 1, TRH induced the marked rise in rectal temperature at 20-80 min, when given to the shamoperated rats, and these rises significantly differed from those in the saline injected, sham-operated rats at 20,40 , 60 and $80 \mathrm{~min}$ after injection $(\mathrm{P}<0.001)$. However, the thyroidectomized rats injected $20 \mathrm{mg} / \mathrm{kg}$ of TRH did not show any significant rise in rectal temperature as compared with those injected saline (Fig. 2).

\section{DISCUSSION}

In the present study, it was observed that TRH caused the rise in rectal temperature in the rat and that the hyperthermia occurred in a dose-dependent manner. The degree of the rises in body temperature ranged from $0.5^{\circ} \mathrm{C}$ to $1.5^{\circ} \mathrm{C}$ as a mean. The hyperthermia appeared early after injection and the duration was not so long. Metcalf (1974) reported hypothermia occurred by intraventricular injection of TRH in the cat and suggested the action of the peptide was similar to that of $\mathrm{Ca}^{++}$or noradrenaline. A dose-related increase in body temperature after intraventricular aaministration of TRH in the rabbit was found by Horita et al. (1975). As for the rat, Kruse (1975) reported TRH antagonized chlorpromazine-induced hypothermia, however, did not significantly raise body temperature. Wei et al. (1975) described intracranial injection of TRH in the rat induced shaking which was considered to be much related to heat gain mechanisms. As far as the effects of this peptide on body temperature are concerned, the results reported previously are conflicting. The same phenomenon is seen in the studies concerned with thermoregulation and brain monoamines. Cooper et al. (1965) pointed out there existed a great species difference as for thermoregulation, especially with its relationship to monoamines. Moreover, experimental condition should be strictly controlled since body temperature is easy to be influenced by such factors as environmental temperature. The present study exhibited that the systemic administration of TRH induced hyperthermia in the rat. The mechanism of the hyperthermia induced by the peptide was uncertain. It appears likely that the action of TRH on body temperature occurred mainly via the thyroid gland since thyroidectomized animals failed to show hyperthermia even after injection of a high dose of TRH $20 \mathrm{mg} / \mathrm{kg}$ which caused the marked rise in body temperature in the sham-operated animals from $20 \mathrm{~min}$ to $80 \mathrm{~min}$ after injection.

According to other evidences obtained in animals, it has been suggested that TRH can possess actions independent of pituitary-thyroid system and 


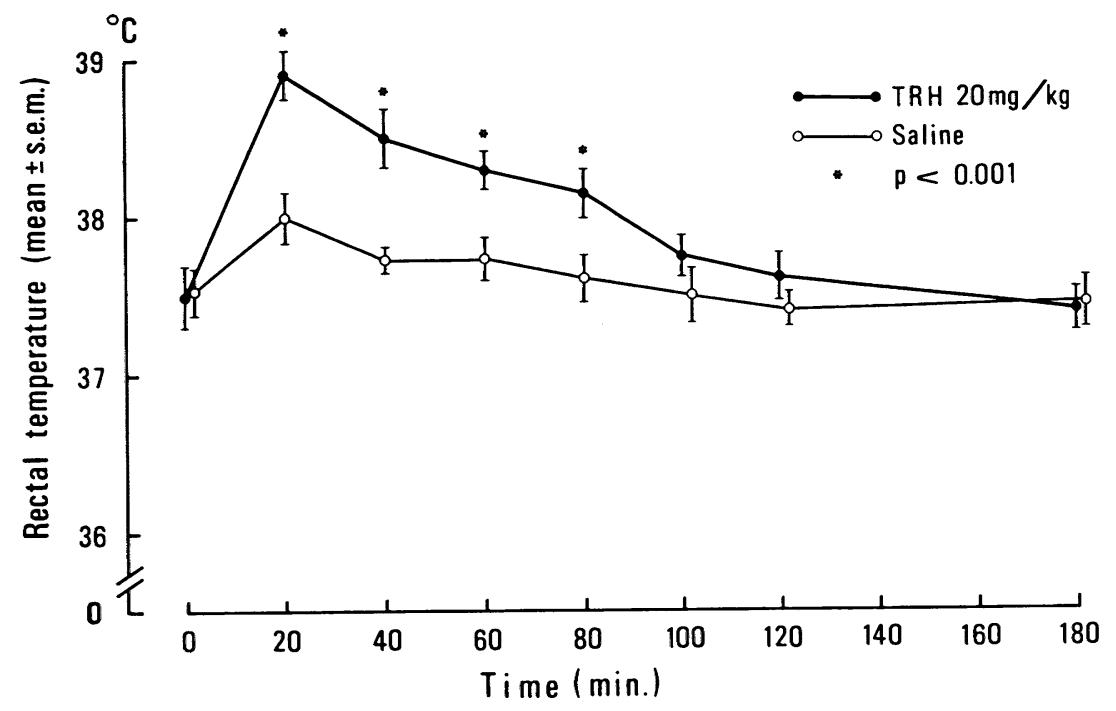

Fig. 1. Time course change in rectal temperature in the sham-operated rats after an i. p. injection of TRH $20 \mathrm{mg} / \mathrm{kg}$ or saline. The experiment was undertaken 10 days after the operation. Each group consists of 10 rats.

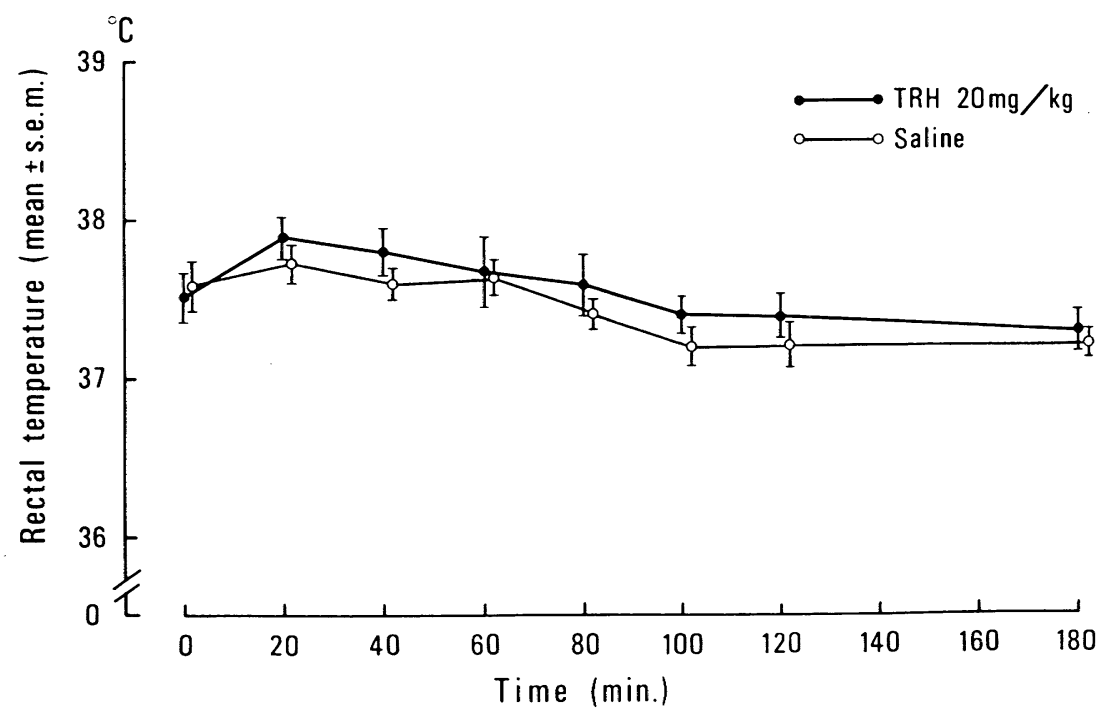

Fig. 2. Time course change in rectal temperature in the thyroidectomized rats after injection of TRH $20 \mathrm{mg} / \mathrm{kg}$ or saline. The experiment was undertaken 10 days after the operation. Each group consists of 10 rats. 
many reports have been published on a relationship between TRH and the brain monoamine metabolism. Constantinidis et al. (1974) suggested the turnover of noradrenaline was enhanced by TRH in the cerebral cortex and hypothalamus of the rat using a fluorescence microscopic method. Keller et al. (1974) investigated about the accumulation of 3 - methoxy - 4-hydroxy phenylethyleneglycol (MOPEG, isolated as the sulphate ester), the major metabolite of noradrenaline in the rat brain after an i. p. injection of TRH and described that TRH probably caused an activation of noradrenergic neuron in the rat brain. Horst and Spirt (1975) reported using $\mathrm{H}^{3}$ - labelled noradrenaline that TRH caused an increase in the release and turnover of noradrenaline in rat brain tissue. Also, Plotnikoff et al. (1974 a, $1974 \mathrm{~b}$ ) reported TRH potentiated the behavioral effects of L-DOPA in the rat. Clinically, Inanaga et al. (1975) reported a relatively small amount of TRH and L-DOPA showed a similar improvement in a certain type of the schizophrenics if administered with a combination of neuroleptics. However, Reigle et al. (1974) described that with the possible exception of a slight enhancement of release, acute or chronic administration of TRH had little effect on the disposition and metabolism of $\mathrm{H}^{3}$ noradrenaline in the rat brain. Plotnikoff (1975) and Miyamoto and Nagawa (1977) suggested the possibility that TRH acted via the dopamine system in the rat brain. As described above, the data in the previous reports on a relationship beween TRH and the brain monoamine metabolism are conflicting similarly as those in many literatures on the role of these monoamines on thermoregulation. However, most reports suggested the turnover of noradrenaline in rat brain was enhanced by TRH treatment. These data being taken into consideration, the enhanced noradrenaline turnover in the brain might be involved in the hyperthermia induced by TRH independent of the mechanism via the thyroid system. However, such possibility seems unlikely and the finding in the study subjected to the thyroidectomized rats, suggests a release of thyroid hormone might mainly participate in the hyperthermic action of the peptide.

\section{ACKNOWLEDGMENTS}

Gratitude is due to Takeda Chemical Industries for a generous supply of TRH tartrate used in the present study.

\section{REFERENCES}

Breese, G.R., Cott, J.M., Cooper, B.R., Prange, A. J. Jr. and Lipton, M. A. (1974). Antagonism of ethanol narcosis by thyrotropin releasing hormone. Life Sci., 14, 1053-1063.

Constantinidis, J, Geissbühler, F., Gaillard, J. M, Hovaquimian, Th. and Tissot, R. (1974). Enhancement of cerebral noradrenaline turnover by thyrotropin-releasing hormone : Evidence by fluorescence histochemistry. Experientia, 30, 1182-1183.

Cooper, K. E. and Cranston, W. I. (1965). Effects of intrahypothalamic injection of noradrenaline and 5-HT on body temperature in conscious rabbits. J. Physiol., 181, 852-864.

Horita, A. and CARino, M. A. (1975). Thyrotropin-releasing hormone (TRH) - induced hyperthermia and behavioral excitation in rabbits. Psychopharmacology Comm, 1, 403-414.

Horst,W.D. and Spirt,N. (1975). A possible mechanism for the anti-depressant activity of thyrotropin releasing hormone. Life Sci, 15, 1073-1082.

InANaga, K., Nakano, T., Nagata, T. and TANAKA, M. (1975a). Effects of thyrotropinreleasing hormone in schizophrenia. Kurume Med. J., 22, 159-168.

InANAGA, K., Oshima, M., Nagata, T. and YA- 
MAUCHI, I. (1975). Behavioral effects of Ldopa and thyrotropin-releasing hormone in schizophrenic patients. A preliminary report. Folia Psychiat. Neurol. Jap., 29, 197-205.

Inanaga, K., Nakano, T., Nagata, T., Tanaka, M. and OGAWA, N. (1978). Behavioral effects of protirelin in schizophrenia. Arch. gen. Psychiat., 35, 1011-1014.

Keller, H. H., Bartholini, G. and Pletcher, A. (1974). Enhancement of cerebral noradrenaline turnover by thyrotropin-releasing hormone. Nature, 248, 528-529.

KRUSE, H. (1975). Thyrotropin-releasing hormone: Interaction with chlor promazine in mice, rats and rabbits. J. Pharmacol. (Paris), 6, 249-268.

MetCALF, G. (1974). TRH : A possible mediator of thermoregulation. Nature, 252, 310-311.

Mry amoto, M. and NaGawa, Y. (1977). Mesolimbic involvement in the locomotor stimulant action of thyrotropin-releasing hormone (TRH) in rats. Europ. J. Pharmacol, 44, 143-152.

Plotnikoff, N. P., Prange, A. J. Jr., Breese, G. R, Anderson, M. S. and Wilson, I. C. $(1974 \mathrm{a})$. The effects of thyrotropin-releasing hormone on DOPA response in normal, hypophysectomized and thyroidectomized animals. In The Thyroid Axis, Drugs, and Behavior (Ed. Prange, A. J. Jr.), Raven Press, New York, pp. 103-113.

Plotnikoff, N. P., Prange, A. J. Jr, Breese, G. R. and Wilson, I. C. (1974 b). Thyrotropin releasing hormone: Enhancement of dopa activity in thyroidectomized rats. Life Sci, 14, 1271-1278.

Plotnikoff, N. P. (1975). Prolyl-leucyl-gly- cine amide (PLG) and thyrotropin-releasing hormone (TRH): Dopa potentiation and biogenic amine studies. In Progress in Brain Research. vol. 42 (Eds. Gispen, W. H., van Wimersma Greidanus, Tj. B., Bohus, B. and de Wied, D.). Elsevier Scientific Pub. Comp., Amsterdam. pp. 11-23.

Prange, A. J. Jr. and Wilson, I. C. (1972 a). Thyrotropin releasing hormone (TRH) for the immediate relief of depression: A preliminary report. Psychopharmacologia, 26, suppl, 82.

Prange, A. J. Jr., Wilson, I. C., Lara, P. P., Alltop, L. B. and Breese, G. R. (1972 b). Effects of thyrotropin-releasing hormone in depression. Lancet, II, 999-1002.

Prange, A. J. Jr, Breese, G. R., Cott, J. M., Martin, B. R., CoOPer, B. R., Wilson, I. C. and Plotnikoff, N. P. (1974). Thyrotropinreleasing hormone: Antagonism of pentobarbital in rodents. Life Sci., 14, 447-455.

Reigle, T.G. Avni, J., Platz,P. A., Schildkraut, J.J. and Plotnikoff, N.P. (1974). Norepinephrine metabolism in the rat brain following acute and chronic administration of thyrotropin releasing hormone. Psychopharmacologia, 37, 1-6.

TAKahashi, S., Kondo, H., Yoshimura, M. and OcHI, Y. (1973). Antidepressant effect of thyrotropin-releasing hormone (TRH) and the plasma thyrotropin levels in depression. Folia Psychiat. Neurol. Jap., 27, 389398.

Wei, E., Sigel, S., Loh, H. and Way, E. L. (1975). Thyrotropin-releasing hormone and shaking behavior in rat. Nature, 253, 739740 . 